\title{
Challenges in Using Literature in English Classroom:The Case of Grade 11 Students in Sodo Preparatory School
}

\author{
Elias Belete Delango \\ Lecturer, Wolaita Sodo University, College of Social Sciences and Humanities, Department of Wolaita \\ Language and Literature, Wolaita Sodo, Sodo, Ethiopia
}

\begin{abstract}
This descriptive-analytic study aimed 1) to investigate the problems that the teachers and students face in using literature to teach English;2) To identify the extent to which the teachers and the students treat the literature provided in grade 11 English textbook; and 3) To identify which literary work is more challenging to teach and to learn English in the classroom. First, some commonly adopted approaches to literature teaching are outlined and specific issues and dilemmas located. Next, using current situation at Wolaita Sodo preparatory school as a case in point, these perceived issues and dilemmas are fleshed out and possible solutions from diverse fronts are then sketched out. This study examined the difficulties facing English teachers in teaching literary texts in English for Ethiopia (grade 11) textbook which has been prescribed by the MOE (Ministry of Education) of Ethiopia from the academic session 2020. Literature has always been an integral part of teaching foreign languages. In the era of CA (Communicative Approach), the aim of reading literature has been changed. From this view point, MOE of Ethiopia has published new textbook version of English textbook for grade-11 classes, and included some literary texts in this book. The emphasis of this literary text is not just on content but on the exploitation of the texts to trigger a variety of language activities. Based on a semi-structured interview with six HSC (Higher Secondary) level English teachers from Wolaita Sodo preparatory school, this study particularly focused on the newly included literary texts to critically evaluate the effectiveness of the materials; and identified the difficulties that the teachers might have encountered. Finally, some recommendations were drawn by means of valuable opinions of the participants. Based on the findings of the study and the conclusions, syllabus designers and textbook writers should take the challenges which both teachers and students face into account and add more explanations on the guide and the textbook that help teachers and students tackle the challenges of literature.
\end{abstract}

Keywords: Challenges, Using Literature, English Classroom, Students, Preparatory School

DOI: $10.7176 /$ RHSS/11-1-01

Publication date: January $31^{\text {st }} 2021$

\section{Introduction}

It had been argued that some limited writing in English began in the early 1960s, inspired by a new sense of curiosity about other cultures and ways of being that the postwar period initiated. Some Ethiopian writers who have lived abroad and become Diaspora writers have adopted English as a second language. Others have managed to write both in English and their native tongues. These writers have internalized the contours or outlines of European literature, and can only write in its conventional forms. The reasons for the choice of English by Ethiopian writers are as varied as the writers themselves. For some, it is simply a matter of taste, a preferred medium of esthetic form; for others, it is a matter of convenience, of gaining access to a wider public through a language of wide international diffusion. In contrast to this, many African writers started complaining about the language choice for every literary work which was dominated by western alien languages.

As Sithamparam (2001) stated, literature is a very useful resource for language learning. McRae (1991) added that by learning literature, it helps to develop the students the four languages skills and their critical thinking skills. McRae (1991:19-20) went on further that reading literature is believed to help students read the world and become better individuals in the society. Research has also been carried out by Lazar (1994:116) and it is proven that literature component brought positive impacts to its learners regardless of the young or adult learners. For the purpose of this study, the researcher divides these possible problems into four main categories. The four categories are the teachers' language, teachers' problems with students, trainings and experiences and the problems of resources. Some examples that fall under the teachers' and experiences as well as the language aspects are the techniques, approaches, exposure and also their knowledge of literature component. McRae (1991:10) stated that some English language teachers feel threatened by their own lack of knowledge.

Beyond the language literature provides students with important comprehension and analysis tools. Through literature, students learn to identify and analyze conflicts, themes, issues and characters. Good texts, either classic or modern literature, contain some universal themes that apply to the students' present and future lives. Learning literature enables students to understand and appreciate cultures and ideologies different from their own in time and space, and to come to perceive traditions of thought, feeling and artistic form within the heritage the literature of such cultures endows (Carter and Long, 1991, P.2).

The greatest pleasure and satisfaction to be found in literature occurs where it brings back to the realities of 
human situations, problems, feelings and relationships (Moody, 1981). Literature offers universal themes which are relevant to students' own experience. It is also a mirror that reflects each learner's perception of the social world. Therefore, literary texts are open to multiple interpretation and genuine interaction (Duff and Mala 1990:6). Students may relate the ideas, events, and things found in literary texts to their own lives. It will stimulate the imagination of the students, to develop their critical abilities and to increase their emotional awareness (Lazar, 1993:19). It also develops pleasure in reading. When EFL learners enjoy reading literature and have motivation to interact with a text, they will develop their reading proficiency. When they try to comprehend the meaning of the text, learners must make references, drawing both on content of the reading and their own experience. The reader is argued to be placed in an active international role in working with and making sense of this literary language (Brimful and Carter, 1986:15).

To achieve such proficiency among their students, English teachers face a number of difficulties in teaching literature in English classroom. Various literary have been incorporated in grade 11 new English text book which has been used since 2003 E.C. It includes, for example, short stories, poems, novel extracts, etc. However, both grade 11 students and teachers of Soddo Preparatory School complain regarding the use of literature on the literary texts incorporated. In this regard, Hussien \& Al-Emami (2016) also claimed that teaching and learning literature could be a daunting task for both teachers and learners, and this is found to be true for those involved in the teaching and learning of English literature at preparatory schools in most Ethiopian schools, but particularly in the Wolaita District in South Ethiopia. The existences of challenges have been identified through the teachers' teaching experience of English in grade 11 since 2003 and informal discussion with them.

As it has been claimed by many scholars, literature is also a part of English language curriculum in Ethiopia. To be successful in teaching and learning, literature in English classroom, both English teachers and students would not have faced challenges in using literature if the right procedure is used. However, as mentioned in the background of the study, both students and teachers were facing a lot of challenges in using literature in English classroom. For instance, (Rodhika, 1991) stated that linguistic difficulty of the text, the background knowledge about English language and culture are the major problems to interpret literature in English classroom.

Moreover, Sullivan, 1991) also stated that there are two major difficulties of literature in language teaching, which are related to linguistic difficulty of the English texts and learners' poor background knowledge about English language and culture to interpret some texts. Some other difficulties that have been identified through the researcher's teaching experience of English in grade 11 for many years, for example, are challenges related to the students' overall lack of competency in English and challenges related to the text such as the abundance of fetched ideas in literature.

Upon joining university, a typical undergraduate Wolaita student would have been exposed only to a brief selection of literary texts. These texts are usually presented to students following the historical approach which focuses on the writer's biography and milieu and the social, cultural, and intellectual context. Indeed, a number of scholars and critics have repeatedly expressed their dissatisfaction with the unrepresentative selections and the traditional and outdated approaches to teaching them (Alamir, 2006). Focusing on the indigenous textbooks for high school, for example, was criticized for focusing on a few and unrepresentative literary eras and themes, excluding some important genres, oversimplifying the discussion of these works, not including any work by the many Wolaita writers as well as excluding all forms of literary analysis.

Furthermore, in the Ethiopian school context in general and Wolaita Sodo Preparatory school grade 11 in particular, foreign, especially Western, literature is often viewed as a threat to the national and Wolaita identity and as a tool of cultural colonization which promotes anti-religious and anti-cultural values. Therefore, though Wolaita native students start taking English as a compulsory subject in grade four, English literature is totally absent from the curricula of public schools.

\subsection{Statement of the Problem}

Literature is part of the English language curriculum in Ethiopia. To be successful in teaching and learning literature in English classroom, both English teachers and students would not face challenges in using literature. However, as mentioned in the background of the study, both students and teachers were facing a lot of different challenges in using literature in English classroom. For instance, (Rodhika, 1991) stated that linguistic difficulty of the text, the background knowledge about English language and culture are the major problems to interpret literature in English classroom.

Moreover, Sullivan, 1991)also stated that there are two major difficulties of literature in language teaching, which are linguistic difficulty of the text and learners' need a lot of background knowledge about English language and culture to interpret some texts. Some other difficulties that have been identified through the researcher's teaching experience of English in grade 11 for many years, for example, are challenges related to the students' overall lack of competency in English and challenges related to the text such as the abundance of for fetched ideas in literature. These affect the students' attitudes towards using literature. As a result, the researcher tried to investigate problems that challenge in using literature in English classroom in Sodo preparatory school the case of 
grade 11 students. The researcher also tried to identify these difficulties and propose some recommendations for overcoming these problems.

Generally, the course plans in the English departments in Wolaita schools and elsewhere in the Wolaita region do not take into consideration the linguistic, cultural and intellectual needs of the students in the region for they are replicas of their counterparts in Western universities. Ironically, English studies programs in England and North America are increasingly moving in the direction of cultural studies and are becoming progressively less exclusive with reference to the English literary canon, school systems in the Ethiopia still thrive on their strictly exclusive English and American curricula in the same way. Therefore, these affect the students' attitudes towards using literature. As a result, the researcher tried to investigate problems that challenge in using literature in English classroom in Sodo preparatory school in the case of grade 11 students.

\subsection{Objectives of the Study}

\subsubsection{General objectives of the Study.}

The general objective of this study was to identify the problems that challenge English language teachers and students in using literature in English classroom

\subsubsection{Specific Objectives of the Study}

The specific objectives of this study were:

* To investigate the problems that the teachers and students face in using literature to teach English.

* To identify which literary work is more challenging to teach and to learn English in the classroom?

* To show the contributing factors while implementing literature in English classroom.

\subsection{Significance of the Study}

From the findings of this study, it was expected that the problems that challenge in using literature in English classroom was identified. Besides, it provided some recommendations which may help the concern bodies for example, syllabus designers that students and teachers challenge in learning English language through literature in English classroom into account and take measures and suggest ways to over-come the problems which were identified when they revise the textbook. Then, the ultimate goal of this study was to recommend procedures that made teaching literature more effective, communicative and interactive through helping teaching to adapt more skill-oriented teaching techniques. This study investigated further study on the issue of problems that challenged in using literature in English classroom; especially teachers may get some useful information as to the students using literature. They may use the findings of this study just to over-come the problems they may encounter in treating literature.

\subsection{Scope of the study.}

The study focused on 2010 E.C grade 11 students in Sodo Preparatory School. It also focused on investigating problems that challenge in using literature in English classroom. As a result, the researcher took grade 11 students and their teachers who teach them in 2010 E.C. academic year into consideration and dealt with problems that challenge teachers in teaching and students in learning English through literature in English classroom.

\section{Research Methodology}

\subsection{The Research Design}

In order to achieve the stated purpose, mixed method approach was employed. According to Creswell (2o12:3), a mixed method research design is a procedure for collecting, analyzing, and mixing both quantitative and qualitative research in a single study to understood a research problem. Wuegbuzie and Leech (2004) stated that mixed method researches (both quantitative and qualitative researches) are important and useful to draw from the strengths and the weakness of both in single research studies and across studies.

More specifically, qualitative research design was employed to have a valid data for the study or gain a better picture of the reality of the issue on the research questions and its objectives in a natural way (Denzin and Lincon, 2000). As a result, the method used to collect qualitative data was interview. In order to compare and determine the relationship between the teachers' and students' challenges in using literature in English classroom, quantitative research design would be used.

\subsection{Population of the Study}

The study was conducted at Sodo Preparatory School which is located in Wolaita Zone in Sodo town. The participants of the study were English language teachers who teach grade 11 students and their students in 2011 E.C. academic year. In this school, the total number of grade 11 students who attended their schooling was 624 and the total number of teachers was four and all of them were used as data sources. These students were assigned in 12 sections. They were both natural and social science streams. In each section, there were 52 students in average. Out of 624 students, 94(15\%) students were selected by using the random sampling technique. According to Berg 
(1983), sampling involved the selection of a portion of a population as representative of the population. A random sampling was one in which each individual in the defined population had an equal chance of being included.

\section{2.1 Sampling Techniques and sample size}

The researcher used simple random sampling techniques to conduct the research. Sampling was the sampling technique in which all students got equal chance to be member of the sample study (Margaret, 2009). Therefore, out of 624 grade 11 students, 94(15\%) students were selected to give the data needed for the research. From this number 36 students were females and 58 students were males. Their age range was from 18 to 21 . The reason that the researcher used this number of people to be respondent to manage their response correctly .In addition, the researcher included all the four grade 11 English Language teachers as a sample because they were fewer in number and easy to manage. Of the total four English language teachers two were male and one was female. Only one teacher was MA in TEFL and two teachers were BA in English language. There age range was from 31 to 4o. The researcher used these respondents to save time, and come up with accurate result.

\subsection{Instruments of Data Collection}

The data required for this study were collected from grade 11 students who attended in 2011 E.C. academic year and their English language teachers in Sodo Preparatory school. In order to collect the relevant information from the samples of the target population for the study, the researcher used questionnaire, classroom observation, and interview as instruments for both students and teachers. And the data collected were analyzed through both quantitative and qualitative approaches.

\section{Discussion and Results}

\subsection{Findings and Interpretations}

This part generally consists of presentation of the statistical results obtained through questionnaires using illustrative tables, observations' result and detail descriptions of the interviews and the possible implications of the results to the research topic.

\subsection{Results of Teachers' questionnaire}

Table 1: Challenges in using literature in English classroom.

\begin{tabular}{|l|l|l|l|l|l|}
\hline No & \multicolumn{1}{|c|}{ Items } & \multicolumn{2}{|c|}{ Yes } & \multicolumn{2}{c|}{ No } \\
\hline 1 & $\begin{array}{l}\text { Have you ever faced any challenges when using } \\
\text { literature to teach English language? }\end{array}$ & F & F & $\%$ \\
\cline { 2 - 6 } & 4 & 100 & - & - \\
\hline
\end{tabular}

Source my own survey

It is argued by (Loughran, 2010), cited in Musthafa (2014), teaching is a very complex enterprise, involving a series of decision-making activities that occur across range of ideas, issues, and events. Teaching is a theoretical act, and theories - whether explicitly or implicitly held - has powerful effects on what teachers do, how they do it, and how they determine if they are successful (Beach et al., 2006, cited in Musthafa, 2014). As teaching comprises various demands - many of them are conflicting one another - teaching requires continual decision making: making judgments about what is considered to be appropriate actions in a given situation at a given time, and this conflicting issue was also indicated in the above table.

To identify what kind of problems they faced in using literature to teach English language in English classroom, different challenges were faced in using literature were presented by the writer of this study. As a result, their responses put in the table below.

Table 2: Challenges that face in using literature

\begin{tabular}{|c|c|c|c|c|c|c|c|c|c|c|c|}
\hline \multirow[t]{3}{*}{ No } & \multirow{3}{*}{$\begin{array}{l}\text { Different challenges in using } \\
\text { literature. }\end{array}$} & \multicolumn{10}{|c|}{ Respondents } \\
\hline & & \multicolumn{2}{|c|}{ Never } & \multicolumn{2}{|c|}{ Sometimes } & \multicolumn{2}{|c|}{ Rarely } & \multicolumn{2}{|c|}{ Always } & \multicolumn{2}{|c|}{ Often } \\
\hline & & $\mathbf{F}$ & $\%$ & $\mathbf{F}$ & $\%$ & $\mathbf{F}$ & $\%$ & $\mathbf{F}$ & $\%$ & $\mathbf{F}$ & $\%$ \\
\hline 1 & Language problem & - & - & 2 & $50 \%$ & - & - & 1 & $25 \%$ & 1 & $25 \%$ \\
\hline 2 & The length of text & - & - & 2 & $50 \%$ & - & - & 1 & $25 \%$ & 1 & $25 \%$ \\
\hline 3 & Cultural unfamiliarity & - & - & 1 & $25 \%$ & 1 & $25 \%$ & 2 & $50 \%$ & - & - \\
\hline 4 & $\begin{array}{l}\text { Lack of background knowledge } \\
\text { about literature. }\end{array}$ & - & - & 1 & $25 \%$ & - & - & 3 & $75 \%$ & - & - \\
\hline
\end{tabular}

Source my own survey

As the above table indicated, $2(50 \%)$ of respondents replied that they sometimes face language problems; $1(25 \%)$ reported for always and $1(25 \%)$ replied that they often face language problem. In relation to this argument, Khan (2011) argues that, identifying the learning barriers to learning English in the Saudi context is particularly important in order to understand the reasons behind students' dissatisfactory level of achievement despite high government expenditure in educational sector. According to Khan, the linguistic barrier and the lack of adequate motivation among both teachers and students are the most crucial at the tertiary level in KSA. The researcher also 
has seen this problem from the interview responses of teachers. They faced the problem of language, especially when teaching poems and novel extracts. They further stated that the words included are not understandable for them easily. The writing styles of literatures are found too difficult for both students and teachers.

According to the length of the text, the researcher has seen that $2(50 \%)$ of respondents responded that they sometimes face the challenges of text length, 1(25\%) always and the rest $1(25 \%)$ replied that they often face the problems of text length. This shows that $50 \%$ of the respondents complained that the literatures which are incorporated in the student's English textbook are too long and too difficult for learners. So the students did not want to read the text. One of teacher respondent argued as follows:

Students might spend most of their time to finish reading the text and it was time consuming to discuss and analyze it. One major problem was that the time spent on students' reading in the class was so long that the teacher did not have enough time left for working on other activities and tasks and that is why most of the time I passed texts without teaching(T4). So this problem affects teachers' in using literature in English classroom.

Few respondents $1(25 \%)$ and $2(50 \%)$ claimed for sometimes facing the cultural unfamiliarity challenge, while $1(25 \%)$ replied rarely. This shows that $(50 \%)$ of the teachers reported that the culture reflected in the literatures might cause great problem in using literature in English classrooms. T2 and T3 complained that the different culture and unfamiliar contexts caused problems that challenge in using literature. These teachers also argued that differences in cultural backgrounds made the literary texts too difficult for the students in order to understand the meanings of some texts. In terms of cultural background they were too difficult for students to make sense of them. From this data the researcher suggested that the students' cultural background should be taken into account when the texts were selected. With reference to the lack of background knowledge challenge about literature, $3(75 \%)$ of respondents replied that they always face and $1(25 \%)$ of respondents replied that they sometimes face challenges in using literature in English classroom.

As the above results indicated that all teachers faced different challenges although the degree of the challenge was different one from the other. For example, the level of education of the reader, the reader's previous knowledge of the subject of the text, the reader's cultural or ethnic background, the reader's political beliefs or views, whether the reader is male or female (reader's sex), the political system in the reader's country etc. Challenges mentioned have been supported by different researches.

Table 3: The literary work which was more challenging

\begin{tabular}{|l|l|l|l|l|l|l|l|l|l|l|l|l|}
\hline No & Item & \multicolumn{2}{l|}{ Novel extracts } & \multicolumn{2}{l|}{ Poems } & \multicolumn{2}{l}{$\begin{array}{l}\text { Short } \\
\text { Stories }\end{array}$} & \multicolumn{2}{l}{$\begin{array}{l}\text { News Paper } \\
\text { Extracts }\end{array}$} & \multicolumn{2}{l|}{ Leaflets } \\
\hline 1 & $\begin{array}{l}\text { Which one of the listed } \\
\text { literary texts was more } \\
\text { challenging when you } \\
\text { teach English language? }\end{array}$ & 1 & $\%$ & $\mathrm{~F}$ & $\%$ & $\mathrm{~F}$ & $\%$ & $\mathrm{~F}$ & $\%$ & $\mathrm{~F}$ & $\%$ \\
\hline
\end{tabular}

Source my own survey

With the reference to table 3,3(75\%) respondents replied that poems became more challenging when they teach English through literature in English classroom and 1(25\%)of respondents replied that novel extracts became more challenging when teaching literature in English classroom. This indicated that poems are the most difficult to teach, compared with other types of literary texts to be used in the language classroom.

The above result was supported by the interview made with both the teachers and students. All the respondents answered that poem was more challenging in using literature to teach and learn English. In addition to this, (Mc Cafferty, 2002) said that Linguistic structure in poems can be confusing; for example, the use of punctuation, capital letter and organization. One of the interviewee reported:

You know, even if I am a teacher still find it difficult to understand and therefore, poems should not be taught to preparatory students because there are ambiguous or vague words in the poem (T2). Similarly, T4 claimed that: Table 4: Types of literary texts that teachers preferred to use in English language classrooms.

\begin{tabular}{|c|c|c|c|c|c|c|c|c|c|c|c|c|c|}
\hline No & Item & \multicolumn{2}{|c|}{$\begin{array}{l}\text { Short } \\
\text { Stories }\end{array}$} & \multicolumn{2}{|c|}{$\begin{array}{l}\text { Novel } \\
\text { Extracts }\end{array}$} & \multicolumn{2}{|c|}{ Poems } & \multicolumn{2}{|c|}{$\begin{array}{l}\text { News } \\
\text { Paper } \\
\text { Extracts }\end{array}$} & \multicolumn{2}{|c|}{ Leaflets } & \multicolumn{2}{|c|}{ Others } \\
\hline \multirow[t]{2}{*}{1} & \multirow{2}{*}{$\begin{array}{l}\text { From the following listed literary } \\
\text { texts, which one do you prefer to } \\
\text { use in English language classroom? }\end{array}$} & $\mathrm{F}$ & $\%$ & $\mathrm{~F}$ & $\%$ & $\mathrm{~F}$ & $\%$ & $\mathrm{~F}$ & $\%$ & $\mathrm{~F}$ & $\%$ & & \\
\hline & & 3 & 75 & - & - & - & - & - & - & - & - & 1 & 25 \\
\hline
\end{tabular}

Source my own survey

As presented in table 4, 3(75\%) of the respondents replied that they prefer short stories to use in English classroom. One of the teachers (T1) explained the reason that they prefer short stories in that they are easier to be dealt with in terms of its length.

In addition to this, T3 suggested that the language of short stories is understandable by the readers. The meanings of the language used in the short stories are clearly and easily stated (T1).From the interview responses 
of teachers, short stories are not challenging for both teachers and the students. 1(25\%) of the respondents preferred non literary texts to use in English classrooms rather than the literary works. In the case of poetry, film extracts and novel extracts, no one preferred to use in English classroom.

"One criticism of using literature in the EFL classroom deals with the overuse of what is called the traditional canon- those famous, classic, award winning literary texts that often contain language that is difficult for a learner to comprehend" (Van, 2009, p. 3). Thus, considering the linguistic proficiency and the present competence level of the students; length of the text; the texts exploiting ability and fitting with curriculum objectives; vocabulary; literary text's ability to stimulate the learners' personal involvement and interest; texts' relevance to life experiences, emotions, or dreams of the language learner, the appropriate genre of literature should be selected. In fact, for students, it is better to select those types of literary texts that are neither too easy nor too difficult. Easy poems and short stories that require students' personal exploration and thus, to unfold their latent talents and creativity should be included. In this regard, considering the proficiency level of our students, even some stories from children's literature can be selected. As Ghosn (1997, cited in Barman \& Basu, 2013, pp.248-249) clarifies that "children's literature, in comparison to adult literature, has simpler language, fewer lengthy stories, fewer abstract ideas, less complicated themes and offers just as wide as a variety of stories." However, care should be taken so that the quality and level of difficulty should not be below the standard.

Table 5: Teachers' responses concerning the clarity and easiness of the literatures.

\begin{tabular}{|l|l|l|l|l|l|}
\hline No & \multicolumn{1}{|c|}{ Items } & \multicolumn{2}{c|}{ Yes } & \multicolumn{2}{c|}{ No } \\
\hline 1 & $\begin{array}{l}\text { Are the literary texts provided in the way you teach easily and } \\
\text { clearly? }\end{array}$ & F & $\%$ & F & $\%$ \\
\cline { 3 - 6 } & 1 & 25 & 3 & 75 \\
\hline
\end{tabular}

Source my own survey

As it can be seen in the table $5,3(75 \%)$ of the respondents answered that the way the literary works presented in grade 11 English textbook is not easy and clear to teach the students. Nevertheless, one teacher (25\%) responded that the way literatures presented is clear and easy. From the above information the researcher understood that almost all the teachers $(75 \%)$ faced the problem of ambiguity and not being easy to teach their students. During the classroom observation, the researcher understood that few students participated actively in responding to the text or sharing their experiences with their class mates. The majority of the students were unwilling to express any ideas. The teachers taught the students in the way they understood. One of the teacher respondents claimed as follows:

Teaching English language through literature is not an easy task. While some problems are general pedagogical problems like students did not read the literary works before the classes and others are specific problems related to literary texts. English language teachers had little experience to teach the literatures and had not been trained to teach literatures in English language which contained some of the problems. The linguistic difficulty of the literature, background knowledge about English language and culture to interpret the literary texts are the major problems in teaching literature. To solve these problems, teachers need training on how they work with literary texts. When teachers were asked for their techniques or mechanisms to overcome linguistic complexities, cultural influence, the length of the text problems they mentioned that they use different techniques. One of the interviewed teachers, for example, T3 suggested the following mechanisms. First, I always try to use my prior knowledge; I tried to relate the topic of the text with specific issues. In addition, I use the context of the text to know its meaning. If it is beyond my capacity, I consult my colleagues who have better knowledge of literatures and English language. I also sometimes use dictionary. Finally, I read the text again and again.

\subsection{Results of students' questionnaire}

In order to gather relevant and tangible information concerning problems that challenge in using literature in English classroom, 7 open ended and 3 close ended questions were prepared and distributed for the subjects of the study or samples who were in grade 11 and assigned in 12 sections. The total number of sample students was 94 (36 females and 58 males)

Table 7: Students' response for close ended and open ended questions.

\begin{tabular}{|l|l|l|l|l|l|}
\hline No & \multicolumn{1}{|c|}{ Items } & \multicolumn{2}{|c|}{ No } \\
\hline 1 & $\begin{array}{l}\text { Have you ever faced any challenges when learning English } \\
\text { language through literature? }\end{array}$ & F & $\%$ & F & $\%$ \\
\cline { 3 - 6 } & 94 & 100 & - & - \\
\hline
\end{tabular}

Source my own survey

As it can be seen in the above table, all the respondents said that they have faced problems when they learn English in using literature. From this answer, the researcher understood that all of the students have the problem of using literatures when they learn English language. In this regard, it is argued that texts that help developing writing, speaking as well as listening, reading should be selected. However, while using literature in the language classroom, skills should never be taught in isolation but in an integrated way and teachers should be trained properly to implement this principle of teaching literature in language classes. 
Table 8: Different challenges in using literature in using literature in English classroom.

\begin{tabular}{|c|c|c|c|c|c|c|c|c|c|c|c|}
\hline \multirow[t]{3}{*}{ No } & \multirow[t]{3}{*}{ Items } & \multicolumn{10}{|c|}{ Level of challenges } \\
\hline & & \multicolumn{2}{|c|}{ Never } & \multicolumn{2}{|c|}{ Some times } & \multicolumn{2}{|c|}{ Rarely } & \multicolumn{2}{|c|}{ Always } & \multicolumn{2}{|c|}{ Often } \\
\hline & & $\mathrm{F}$ & $\%$ & $\mathrm{~F}$ & $\%$ & $\mathrm{~F}$ & $\%$ & $\mathrm{~F}$ & $\%$ & $\mathrm{~F}$ & $\%$ \\
\hline 1 & Language level challenge & - & - & 28 & 29.78 & - & - & 61 & 64.89 & 5 & 5.31 \\
\hline 2 & The length of the text & - & - & 56 & 59.57 & - & - & 20 & 21.27 & 18 & 19.14 \\
\hline 3 & Culture difficulty & 6 & 6.38 & 37 & 39.36 & 3 & 3.19 & 37 & 39.36 & 11 & 11.70 \\
\hline 4 & $\begin{array}{l}\text { Lack of background } \\
\text { knowledge about literature }\end{array}$ & - & - & 22 & 23.40 & 2 & 2.12 & 53 & 56.38 & 17 & 18.05 \\
\hline
\end{tabular}

Source my own survey

Moreover, as can be seen from the above table, according to language level challenge, 61(64.89\%) of the students replied that they always face the language difficulty; $28(29.78 \%)$ of the students answered that as they sometimes face the language difficulty and 5(5.31\%) of the respondents replied that they often face the language problem. With regard to the length of the text challenge, $50(53.19 \%)$ of the respondents answered that they sometimes face the length of the text challenge, 6(6.38\%) rarely, $20(21.27 \%)$ always and 18(19.14\%) often. According to cultural problem, student respondents replied as it was indicated in the above table. More report from table- 8 depicted that lack of background knowledge challenge students' language learning if literature is used in the classroom (i.e. $53(56.38 \%)$ respondents answered for always, $22(23.40 \%)$ for sometimes, $2(2.12 \%)$ for rarely and $17(1805 \%)$ for often). Thus, the data reflects that much has to be done on the implementation of literature in EFL classroom.

The students were asked to list any challenge in the open ended question number 3. For this reason, many of them added other problems which were not mentioned so far. These challenges are as follows.

- Teachers lack of ability and experience to teach; The inclusion of so much unfamiliar words in the texts; Teachers focus on grammar; Inadequate or no sufficient literary texts at school library; Teachers' attitudes in the field of teaching and Teachers' lack of motivation etc.

Table 9: Literary texts which were more challenging.

\begin{tabular}{|c|c|c|c|c|c|c|c|c|c|c|c|c|c|}
\hline No & Item & & $\begin{array}{l}\text { rt } \\
\text { ries }\end{array}$ & & & & & & lets & $\begin{array}{l}\text { News } \\
\text { Extracts }\end{array}$ & Paper & & hers \\
\hline \multirow[t]{2}{*}{1} & \multirow{2}{*}{$\begin{array}{l}\text { Which one of the } \\
\text { listed literary } \\
\text { texts was more } \\
\text { challenging to } \\
\text { you learn } \\
\text { English } \\
\text { language? }\end{array}$} & $\mathrm{F}$ & $\%$ & $\mathrm{~F}$ & $\%$ & $\mathrm{~F}$ & $\%$ & $F$ & $\%$ & 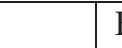 & $\%$ & & \\
\hline & & - & - & 21 & 22.34 & 60 & 63.8 & 5 & 5.31 & & 8.51 & - & - \\
\hline
\end{tabular}

Source my own survey

Understanding and appreciating a literary text requires the use of critical and individual thinking. However, in most Wolaita educational institutions, rote memorization is considered the chief learning method. So, teaching students about short stories, novel, poems and newspaper extracts is found so difficult especially students who are learning English as a foreign language, and that is why learning English has been hated by several students of Wolaita nation. EFL teachers were also reported ignorant of using literature and its sources in the classroom because of various factors mentioned above.

Teachers of Wolaita nation are recruited into an educational program in different times and under different contextual forces. Some teachers were recruited into an academic program as a result of relatively competitive recruitment processes; while other teachers have joined the teaching force in response to an invitation for letters of application which means being admitted to the academic post without a rigorous academic screening process.

Viewed from their academic qualifications and fields of expertise, teachers are also varied. While this variety in itself is potentially beneficial, because of its possibility for synergy, imbalance of the proportion and distribution of expertise can pose a serious challenge for productive program implementation. Take for example teachers' association: out of the total teachers, only few teachers with some experiences and interest in literature. In Ethiopia, teachers with interest in literature make up only $20 \%$ of the total (and the other remaining $80 \%$ come from various languages, including mother tongue-Wolayttatto background). The same picture of imbalance is also clear in University: there are only few lecturers who are interested (and therefore willing to teach courses) in literature compared to ten or so lecturers with linguistics background.

This imbalanced proportion of human resources in the program can pose serious problems, including lowquality literature instruction and this, in turn, sends a negative message to the public. It is probably because of this low-quality instruction that only $20 \%$ of students at school chose literature major while the remaining majority opted for others. 
Table 10: Students' Responses Concerning the Celerity and Easiness of the Literatures.

\begin{tabular}{|l|l|l|l|l|l|}
\hline No & \multicolumn{1}{|c|}{ Items } & \multicolumn{2}{|c|}{ Yes } & \multicolumn{2}{c|}{ No } \\
\hline 1 & $\begin{array}{l}\text { Are the literary works presented in the way you learn } \\
\text { easily and clearly? }\end{array}$ & F & $\%$ & F & $\%$ \\
\cline { 2 - 6 } & 9 & 9.57 & 85 & 90.43 \\
\hline
\end{tabular}

Source my own survey

As it can be seen in above table, almost all the respondents $85(90.42 \%)$ replied that the literary texts presented were not easy and clear. Nevertheless, $9(9.57 \%)$ of the respondents answered that the literatures presented were clear and easy. From this answer, the researcher understood that the majority of the students were in the problem of using literature in English classrooms.

Table 11: Students' responses concerning reasons for lack of interest to learn English using literature.

\begin{tabular}{|l|l|l|l|l|l|}
\hline No & \multicolumn{1}{|c|}{ Items } & \multicolumn{2}{c|}{ Yes No } \\
\hline 1 & $\begin{array}{l}\text { Are you interested in learning English language through } \\
\text { literature? }\end{array}$ & F & $\%$ & F & $\%$ \\
\cline { 3 - 6 } & 28 & 29.79 & 66 & 70.21 \\
\hline
\end{tabular}

Source my own survey

As can be seen in table $11,66(70.21 \%$ ) of the respondents replied that they were not interested in learning English through literature. However, 28(29.78\%) of the respondents claimed that they were interested in learning English using literature in English classrooms due to difficult literary language expressions, shortage of experience in literary texts, nature of the topic, lack of the students' motivation, lack of support by teachers, the inclusion of unfamiliar words, lack of confidence in the learners, and poor background knowledge from the students.

\section{CONCLUSIONS}

This descriptive-analytic study aimed 1) to investigate the problems that the teachers and students face in using literature to teach English; 2) To identify the extent to which the teachers and the students treat the literature provided in grade 11 English textbook; and 3) To identify which literary work is more challenging to teach and to learn English in the classroom. First, some commonly adopted approaches to literature teaching are outlined and specific issues and dilemmas located. Next, using current situation at Wolaita Sodo preparatory school as a case in point, these perceived issues and dilemmas are fleshed out and possible solutions from diverse fronts are then sketched out. This study examined the difficulties facing English teachers in teaching literary texts in English for Ethiopia (grade 11) textbook which has been prescribed by the MOE (Ministry of Education) of Ethiopia from the academic session 2020. Literature has always been an integral part of teaching foreign languages. In the era of CA (Communicative Approach), the aim of reading literature has been changed. From this view point, MOE of Ethiopia has published new textbook version of English textbook for grade-11 classes, and included some literary texts in this book. The emphasis of this literary text is not just on content but on the exploitation of the texts to trigger a variety of language activities. Based on a semi-structured interview with six HSC (Higher Secondary) level English teachers from Wolaita Sodo preparatory school, this study particularly focused on the newly included literary texts to critically evaluate the effectiveness of the materials; and identified the difficulties that the teachers might have encountered. Finally, some recommendations were drawn by means of valuable opinions of the participants. Based on the findings of the study and the conclusions, syllabus designers and textbook writers should take the challenges which both teachers and students face into account and add more explanations on the guide and the textbook that help teachers and students tackle the challenges of literature.

\section{References}

Abu, A. (2004). The reader, the text, the poem: The transactional theory of the literary work. Carbondale, IL: Southern Illinois University Press.

Alkubaidi, M. (2014). The Relationship between Saudi English Major University Students'Writing Performance and their Learning Style and Strategy Use. English Language Teaching, 7(4), 83-95.

Barman, B., \& Basu, B. L. (2013). Approaches and methods of language learning. Dhaka: Friends' Book Corner. Cai, M. (2002). Multicultural Literature for Children and Young Adults: Reflections on Critical Issues. Westport: CT: Greenwood Press.

Carter, R. and Long, M. (1991). Teaching Literature. Hong Kong: Longman.

Duff, A. and Maley, A.(1990). Resource Books for Teachers: Literature. Oxford: OUP.

Gall, J.P. and Walter,R.B. (1996). Educational Research: An Introduction (6 ${ }^{\text {th }}$ Ed.). White Plains, New York: Longman Publishers, USA.

Hussein, E. T. Al-Emami, A.H. (2016). Challenges to Teaching English Literature at the University of Hail: Instructors' Perspective. Arab World English Journal, 7(4)DOI https://dx.doi.org/10.24093/awej/vol7no4.9

Ibrahim, S. (2015). Saudi Students' Perspectives on Increasing their Meta-linguistic Awareness in the Differences between Arabic and English Word Order Using Explicit Form-focused Instruction (Doctoral dissertation, Mount Saint Vincent University).

Koul, L. (1984). Methodology of Educational Research (3 $3^{\text {rd Revised }}$ Ed.). New Delhi: Vishal Printers. 
Khan, I. (2011). An Analysis of Learning Barriers: The Saudi Arabian Context. International Education Studies, $4(1), 242-247$.

Kashta, J. (2000). What expert teachers do. Crows Nest NSW: Allen \& Unwin.

Lazar, G. (1993). Literature and language teaching: A guide for teachers and trainers. New York: Cambridge University Press.

(1994). Improving students' English speaking proficiency in Saudi public schools. International Journal of Instruction, 8 (1), 105-116.

Matson, Susan. (2016, March). Acclimatizing Saudi Students. Language Magazine. http://languagemagazine.com/?page_id=6364

McRae, C., R. (1991). The Routledge History of Literature in England. London: CUP.

Mertler, C.A. and Charles, C.M. (2005). Introduction to Educational Research $\left(5^{\text {th }}\right.$

Seliger,H.W.and Shohamy,E.(1989).Second Language Research Methods. Oxford: OUP.

Sithamparam, E. (2001). Research into the Teaching of Literature in a Second Language:

What It Says and How to communicate it to Graduate Students. In V. Scott \& H. Tucker (Eds.), SLA and the literature classroom: Fostering dialogues. Boston, MA: Heinle \& Heinle.

Van, T. T. M. (2009). The relevance of literary analysis to teaching literature in the EFL classroom. English Teaching Forum, 3, 2-9. 